\title{
Alfredo Lleras Pizarro 1908 - 1978
}

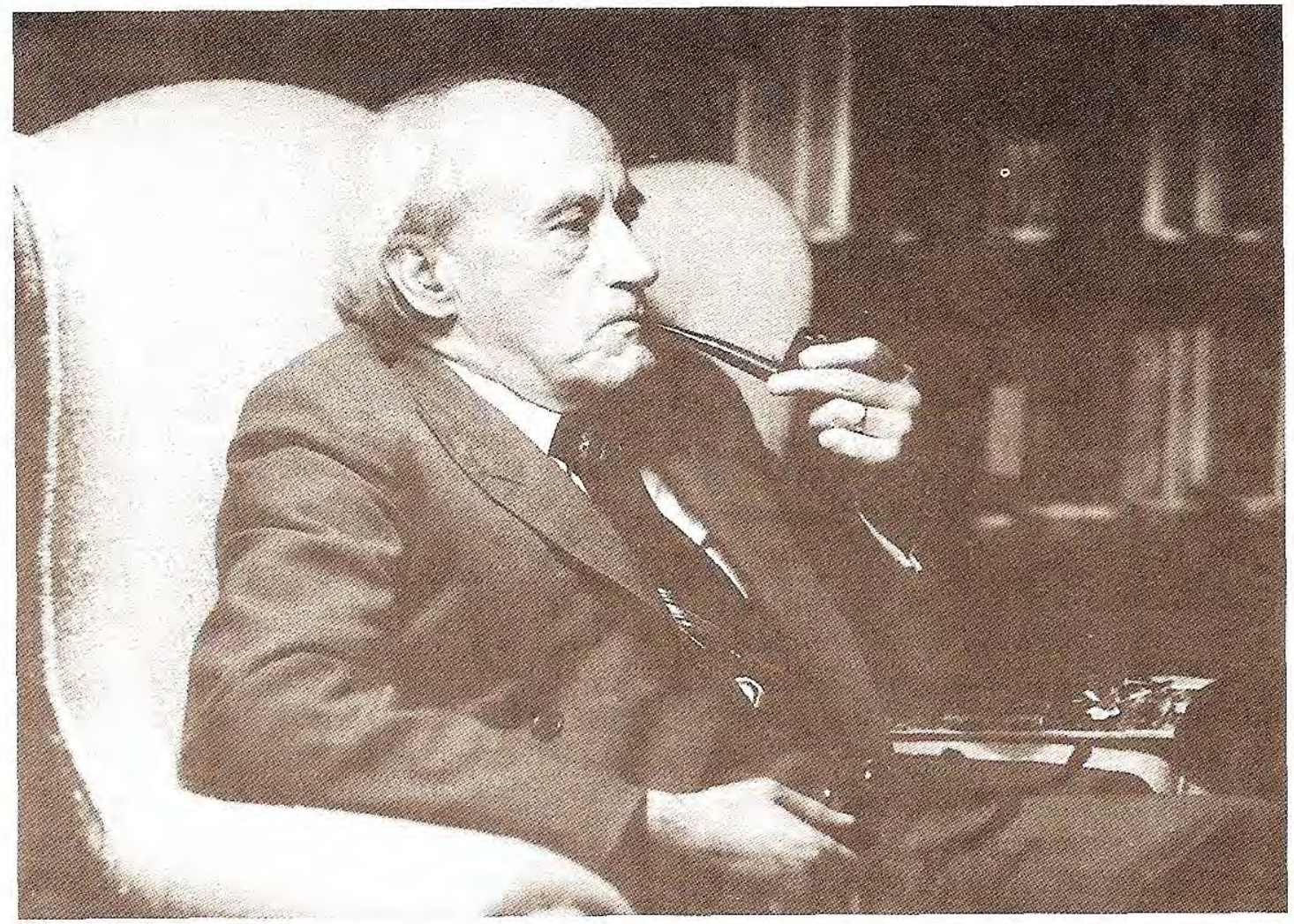

1908 Nace en Bogotá el 23 de marzo.

1925 Bachiller del Instituto La Salle.

1926-32 Carrera de medicina, Universidad Nacional de Colombia.

1933 Oficial de Sanidad en la campaña con el Perú (Caquetá, Putumayo, Amazonas).

1934 Médico cirujano; diploma firmado, entre otros, por Roberto Franco.

1935-36 Médico jefe de la Sanidad del Bajo Atrato.

1936-38 Médico de los asilos de niños de la Beneficiencia de Cundinamarca.

1939 Llamado al servicio activo del ejército, es destinado a la sanidad de la Base Aérea Germán Olano.

1940-43 Médico jefe de la zona de carreteras de Santander.
1943 Se vincula al Instituto Nacional de Higiene Samper Martínez donde desarrolla su actividad profesional.

Se desempeñó sucesivamente como jefe de diagnóstico bacteriológico, de control biológico, de epidemiología y de virología; varias veces fue encargado de la Dirección de este instituto.

Su actividad investigativa la dedicó de manera muy preferencial a la rabia, pero, se ocupó también de la influenza, fiebre aftosa, brucelosis, enterovirus, encefalitis y arbovirus, sobre todo dengue.

Entre otros lauros, fue distinguido como Comendador de la Orden Javeriana y recibió la Medalla Jorge Bejarano del Ministerio de Salud Pública; en ambos casos, la intención fue exaltar a un silencioso y tímido obrero de la ciencia y al ciudadano ejemplar.

Falleció el 8 de febrero de 1978. 